\title{
Air pollution from traffic emissions in Oporto, Portugal: Health and environmental implications
}

\author{
Klara Slezakova $^{\mathrm{a}, \mathrm{b}}$, Dionísia Castro ${ }^{\mathrm{a}, \mathrm{b}}$, Arlindo Begonha $^{\mathrm{c}}$, Cristina Delerue-Matos $^{\mathrm{b}}$, \\ Maria da Conceição Alvim-Ferraz ${ }^{a}$, Simone Morais ${ }^{b}$, Maria do Carmo Pereira ${ }^{a}$, \\ a LEPAE, Departamento de Engenharia Química, Faculdade de Engenharia, Universidade do Porto, R. Dr. Roberto Frias, $4200-465$ Porto, \\ Portugal \\ b REQUIMTE, Instituto Superior de Engenharia do Porto, R. Dr. António Bernardino de Almeida 431, $4200-072$ Porto, Portugal \\ C Departamento de Engenharia Civil, Faculdade de Engenharia, Universidade do Porto, R. Dr. Roberto Frias, $4200-465$ Porto, Portugal
}

\begin{abstract}
Air pollution represents a serious risk not only to environment and human health, but also to historical heritage. In this study, air pollution of the Oporto Metropolitan Area and its main impacts were characterized. The results showed that levels of CO, PM10 and SO2 have been continuously decreasing in the respective metropolitan area while levels of NOx and NO2 have not changed significantly. Traffic emissions were the main source of the determined polycyclic aromatic hydrocarbons (PAHs; 16 PAHs considered by U.S. EPA as priority pollutants, dibenzo[a,l]pyrene and benzo[j]fluoranthene) in air of the respective metropolitan area. The mean concentration of $18 \mathrm{PAHs}$ in air was $69.9 \pm 39.7 \mathrm{ng} \mathrm{m}-3$ with 3-4 rings PAHs accounting for $75 \%$ of the total $\Sigma \mathrm{PAHs}$. The health risk analysis of PAHs in air showed that the estimated values of lifetime lung cancer risks considerably exceeded the health-based guideline level. Analytical results also confirm that historical monuments in urban areas act as passive repositories for air pollutants present in the surrounding atmosphere. FTIR and EDX analyses showed that gypsum was the most important constituent of black crusts of the characterized historical monument Monastery of Serra do Pilar classified as "UNESCO World Cultural Heritage". In black crusts, 4-6 rings compounds accounted approximately for $85 \%$ of $\Sigma$ PAHs. The diagnostic ratios confirmed that traffic emissions were the major source of PAHs in black crusts; PAH composition profiles were very similar for crusts and PM10 and PM2.5.
\end{abstract}

\section{Keywords:}

Air pollution, Traffic emissions, Polycyclic aromatic hydrocarbons (PAHs), Health risks, Historical monuments, Black crusts

\section{Introduction}

During last three decades special efforts have been made in Europe aiming to reduce air pollution and, more importantly, to reduce the adverse impacts of atmospheric pollutants. Although these efforts led to a reduction of risks and effects, air pollution in Europe is still a matter of concern. In that regard pollution from industrial sources or vehicular traffic is especially important, because its volume is increasing every year [1]. The implementation of some policy measures led to significant decrease of some pollutants, such as lead or sulfur dioxide (SO2), whereas other, potentially even more hazardous pollutants, such as nitrogen oxides (NOX), carbon monox- ide (CO), and particulate matter (PM) containing polycyclic aromatic hydrocarbons (PAHs) and heavy metals [2], are emitted into the atmosphere in great amounts, causing significant decline of air quality across Europe [3]. These pollutants represent a serious risk for human health; it was estimated that in Europe thousands of premature deaths are annually attributed to poor air quality alone [4].
Polycyclic aromatic hydrocarbons are one of the priority air pollutants due to their extremely hazardous properties to human health. Many of the individual PAHs are cytotoxic and mutagenic to both lower and higher organisms [5], some of them being considered as carcinogens (probable and possible) to humans $[6,7]$. Out of the 16 compounds classified as priority pollutants by US EPA [8], benzo[a] pyrene (class A carcinogen) is probably the most known PAH carcinogen; in many studies that estimate human cancer risk it is used as a surrogate for other carcinogenic PAHs. Even current European legislation for ambient air [9] uses benzo[a]pyrene as indicator for carcinogenic PAHs. Nevertheless, the suitability of this approach started to be questioned [10] by new findings on the presence of more potent PAHs, such as dibenzo[a,I]pyrene or dibenz [a]anthracene that are estimated to have a carcinogenic potency approximately 100 and 5 times higher, respectively, than benzo[a] pyrene [11]. However, environmental studies that include these compounds are scarce [10-14].

The effects of air pollution are not confined only to human health or environment but also to building materials. Deposition of atmospheric pollutants on surfaces represents one of the most important deterioration phenomena that affect façades of the historical building and monuments [15]. Typically, the damage layers 


result from the deposition of both organic and inorganic pollutants $[16,17]$ that are transferred to the respective surfaces by both dry and wet processes $[18,19]$. The effects of deposition processes may consist in blackening of the monument façades; the wet and dry depositions are often combined with gypsum crystal growth resulting in formation of a hard, gray to black crusts, in which airborne organic pollutants and a wide range of particulate matter (including dust, pollen, and spores) are entrapped in the mineral matrix $[18,20,21]$. Air pollution impacts can have permanent consequences that can lead to potential losses of these irreplaceable structures forever.

Oporto (NW Portugal) is one of the oldest European cities [22]. It was founded on the northern bank of the Douro River. Excavations near its Cathedral revealed several buildings from the 2 nd century BC [22]. Considering the unique features of its

historical center, the city was classified in 1996 as "UNESCO

World Cultural Heritage". Despite its cultural values, the

façades of monuments and historical buildings have been deteriorating, showing intense loss of materials and blacking, as consequence of the general presence of thin black layers and black crusts, mainly due to pollutants deposition. In that regard, traffic emissions have become a major problem as the motorization rate of Oporto Metropolitan Area (Oporto $\mathrm{MA}$ ) is the second largest one in Portugal [23]. Consequently, this urban area is significantly affected by traffic emissions $[24,25]$, and the limit values of European Directives $[9,26]$ have been exceeded during the past years [24,25,27]. The developed work aimed to characterize air pollution of the Oporto MA and its main impacts. The specific objectives of this work were to assess: (1) the levels of the more relevant pollutants in ambient air; (2) the health risks associated with exposure to PM and PAHs; and (3) the deposition patterns and stone decay of the historical monument Monastery of Serra do

Cultural Heritage".

Pilar classified as "UNESCO World

2. Material and methods

\subsection{Sampling}

ThelevelsofCO,SO2, NO2, NOx, and PM10 (i.e. particulate matterwith aerodynamic diameter below $10 \mu \mathrm{m}$ ) were collected in Oporto
Metropolitan Area at the monitoring station characterized as urban traffic site. Since PAHs are not routinely monitored by the national monitoring network, the levels of the 16 compounds recommended by

U.S. EPA as priority pollutants, and of dibenzo[a,I]pyrene (with carcinogenic potency 100 times higher than benzo[a]pyrene [11]) and benzo[j]fluoranthene (recommended by EU Directive 2004/107/EC [9])were monitored separately in the respective area (40 days during autumn-winter 2008). The samples of $\mathrm{PAHs}$, both in gas and particulate phases were collected daily. Sampling was done by constant flow samplers (Bravo H2, TCR TECORA, Italy) that were combined with PM EN LVS sampling heads for gaseous and particulate samples (in compliance with norm EN12341 for PM10 and EN14907 for PM2.5; i.e. particles with aerodynamic diameter below $2.5 \mu \mathrm{m}$ ); an air flow rate of

$2.3 \mathrm{~m}^{3} \mathrm{~h}^{-1}$ was used. The different fractions of PM10 and PM2.5 were

collected on polytetrafluoroethylene (PTFE) membrane filters with polymethylpentene support ring ( $2 \mu \mathrm{m}$ porosity, $\varnothing 47 \mathrm{~mm}$, SKC Ltd., United Kingdom). Gaseous PAHs were collected on polyurethane foam (PUF) plugs (75 mm, SKC Ltd., United Kingdom) that were pre-cleaned using the following procedure [28]: boiling in deionized water, followedby rinsing with acetone (Riedel-de Haën, Seelze, Germany, purity 99.8\%) and then Soxhlet extracted twice during $24 \mathrm{~h}$ with n-hexane (Chromasolv, Merck, Darmstadt, Germany).

The samples of black crusts were collected in December of 2008 in the Monastery of Serra do Pilar (Fig. 1) that is situated on the left bank of river Douro, approximately $1.5 \mathrm{~km}$ near to the monitoring station. The convent was built in the sixteenth century, being designed by Diogo de Castilho and João de Ruão. The circular ground-planned church with impressive dome was also built in the sixteenth century with a narrow balcony and a lantern on the roof. Adjoining the church there is a cloister, also circular, with 36 Ionic columns. In order to obtain representative samples, the black crusts were collected at points with different solar orientation; being sheltered from the direct action of rainfall (Fig. 1).

\subsection{Black crusts characterization}

The morphological and elemental characterization of collected crusts was performed by Scanning Electron Microscopy (SEM) using 
A

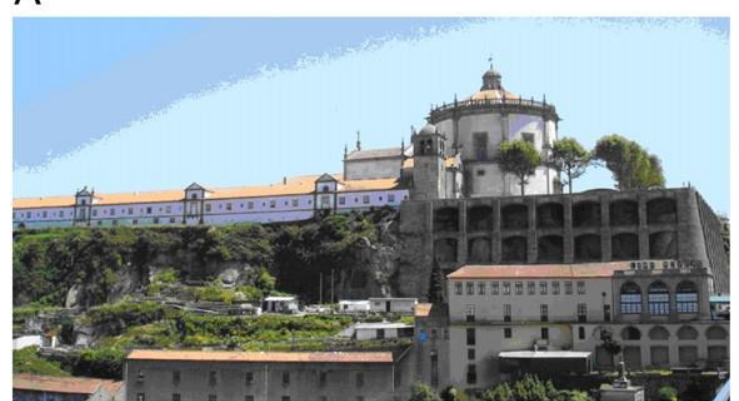

C

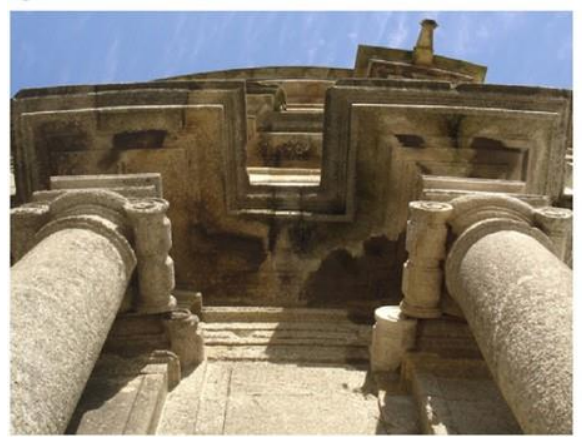

B

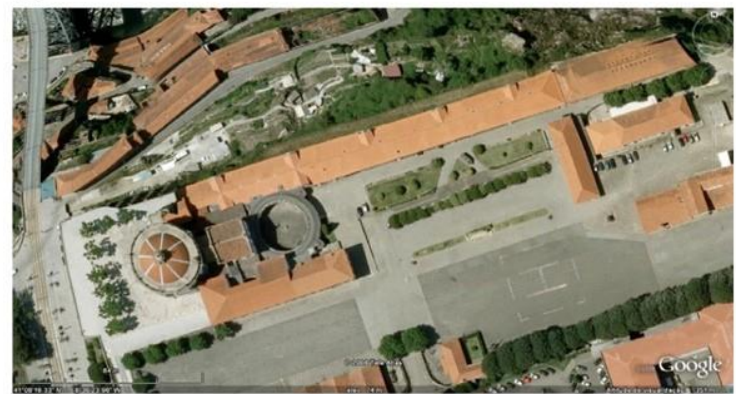

$\mathrm{E}$
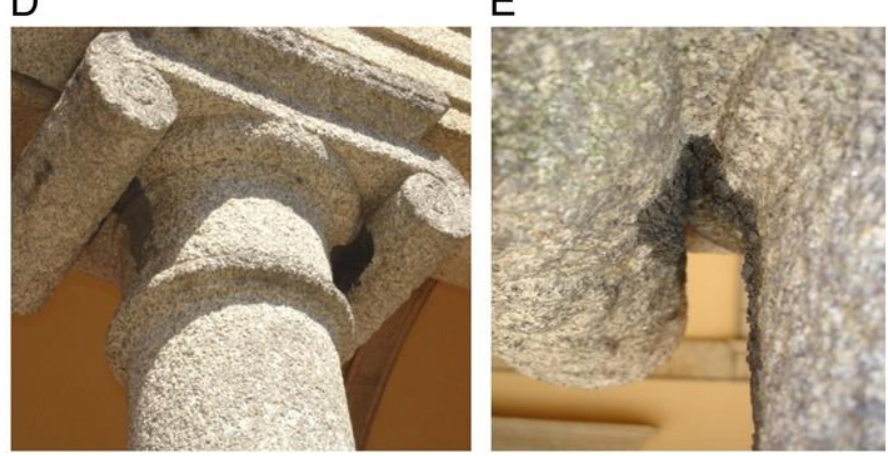

Fig. 1. The Monastery of Serra do Pilar: (A) general view; (B) satellite image of the whole complex; (C) church portal; (D) columns in cloister; and (E) detail view of a sampling point. 
the microscope model FEI Quanta FEG combined with an $X$-ray microanalysis system by energy dispersive spectrometer (EDX) EDX EDAX Pegasus X4M. Black crust samples were placed and mounted (Araldite ${ }^{\circledR}$, Huntsman Advanced Materials, USA) on aluminum stubs. For better conductivity and reduction of electron charge, the samples were coated with a carbon layer. Acceleration voltage of $15 \mathrm{keV}$ and $\mathrm{X}$ - ray spectrum acquisition time of $200 \mathrm{~s}$ live time were used.

The Fourier Transform Infrared Spectroscopy (FTIR) was per- formed using spectrometer model BOMEN, MB model. For the analysis, homogenized black crust samples were mixed with $\mathrm{KBr}$ (Sigma Aldrich) in ratio 1:1. In order to evaluate spectras correctly, a pure $\mathrm{KBr}$ background was collected and subtracted from all samples spectra.

\subsection{Extraction of PAHs}

The extractions of PAHs from crusts, particles (PM10 and PM2.5) and PUF plugs were performed by microwaveassisted extraction (MAE; MARS-X 1500 W Microwave Accelerated Reaction System for Extraction and Digestion, CEM, Mathews, NC, USA) [29]. Samples were transferred to the glass extraction vessels with 20,30 and $45 \mathrm{~mL}$ of acetonitrile (Lichrosol for gradient elution, Carlo Erba, Rodano, Italy, purity $\mathrm{N}$ 99.9\%), respectively, for crusts (approximately $500 \mathrm{mg}$ of homogenized sample), filters and PUF plugs. The MAE was performed for $20 \mathrm{~min}$ at $110^{\circ} \mathrm{C}$. After the extraction, vessels were allowed to cool at room temperature; extracts were carefully filtered through a PTFE

membrane filter $(0.45 \mu \mathrm{m})$ and reduced to a small volume using a

rotary evaporator (Buchi Rotavapor, R-200) at $20^{\circ} \mathrm{C}$. A gentle stream of nitrogen was used to dry the extracts under low temperature; the

residue was then re-dissolved in $1 \mathrm{~mL}$ of acetonitrile immediately

before

analysis.

\subsection{PAHs chromatographic analysis}

Extracts were analyzed using a Shimadzu LC system (Shimadzu Corporation, Kyoto, Japan) equipped with a LC20AD pump, DGU- 20AS degasser and photodiode array SPDM20A (PAD) and fluores- cence RF-10AXL (FLD) detectors on line [29]. Separation of the compounds was performed in a C18 column (CC 150/4 Nucleosil 100-5C18 PAH, 150×4.0 mm; $5 \mu \mathrm{m}$ particle size; Macherey-Nagel, Duren, Germany) maintained at room temperature $\left(20 \pm 1{ }^{\circ} \mathrm{C}\right)$. The injected volume was 15.0 $\mu \mathrm{L}$. A mixture of water and acetonitrile was used as the mobile phase. The initial composition of the mobile phase was $50 \%$ of acetonitrile and $50 \%$ ultra-pure water, and a linear gradient to and $181 \mathrm{pg} \mathrm{m}^{-3}\left(10 \mathrm{\mu g} \mathrm{L}^{-1}\right)$ for acenaphthylene were obtained, withcorresponding LOQs in the range 5.4-652 pg $\mathrm{m}^{-3}\left(0.30-36 \mu \mathrm{g} \mathrm{L}^{-1}\right)$.

During each set of MAE extractions, a filter blank or a PUF plug blank was included. Standards used for calibration were analyzed daily and regularly, as well as blank MAE extracts (from filter blank or PUF plug blank), between samples to check instrument performance during PAHs analysis. Each analysis was run at least in triplicate.

\subsection{Health risk analysis}

The analysis of the health risks associated with inhalation exposure to PM10 was based on the estimation of dose rates and the lowest observed adverse health effect levels (loael). The calculation of health risks was done using the following equation [30]:

Health risk $=$ hose rate $=$ loael

where loael is the lowest tested pollutant dose that has been reported to cause adverse health effects on people or animal. If the dose rate exceeds this threshold (i.e. if Health risk=[Dose rate/loael] exceeds unity), there may be concern for potential health risk of occupants associated with inhalation exposure of particulate matter. Four different age-categories were used for the estimation of PM health risks, namely new-borns, children (1-year), children (8-10 years), and adults. The dose rates were estimated through the following expression over a day:

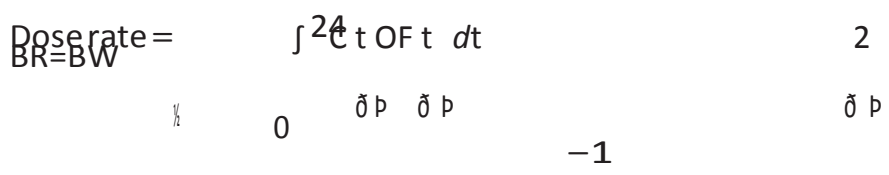

minsidering the respective age-specific ( $L$ ) breathißgg rates $(B R)$, body weights $(\mathrm{kg})$, concentration of the pollutant $\quad ; \mathrm{C}(\mathrm{t}))$; and ( $\mu \mathrm{gm}$

$100 \%$ of acetonitrile was programmed in $15 \mathrm{~min}$, with a final hold of $13 \mathrm{~min}$. Initial conditions were reached in $1 \mathrm{~min}$ and maintained for $6 \mathrm{~min}$ before next run. The total run time was 40 min with a flow rate of

$0.8 \mathrm{~mL} \mathrm{~min}{ }^{-1}$. Fluorescence wavelength programming was used to

perform better sensitivity and minimal interference. Each compound was detected at its optimum excitation/emission wavelength pair: $260 / 315 \mathrm{~nm}$ (naphthalene, acenaphthene and fluorene), 260/366 nm (phenanthrene), 260/430 nm (anthracene, fluoranthene, pyrene, benz[a]anthracene, chrysene, benzo[b + j]fluoranthene, benzo[k] fluoranthene, benzo[a]pyrene, dibenz[a,h]anthracene, benzo[ghi]per- ylene and dibenzo[a,I]pyrene), and 290/505 nm (indeno[1,2,3-cd] pyrene). Acenaphthylene which does not show fluorescence 
was analyzed at $254 \mathrm{~nm}$ in PAD.

External calibrations with PAHs mixed standards, using at least 6 calibration points, were performed. Calibrations curves were linearly fitted with correlation coefficients always higher than 0.9997 for all PAHs. Limits of detection (LODs) and limits of quantification (LOQs) were calculated as the minimum detectable amount of analyte with a signal-to-noise ratio of 3:1 and 10:1, respectively [30], and expressed as $\mathrm{PAH}$ concentration in solution ( $\left.\mathrm{gg} \mathrm{L}^{-1}\right)$ and in air samples $\left(\mathrm{pg} \mathrm{m}^{-3}\right)$ [29]. LODs between $1.6 \mathrm{pg} \mathrm{m}^{-3}\left(0.090 \mu \mathrm{g} \mathrm{L}^{-1}\right)$ for benz[a]anthracene percentage of time likely to spent outdoor $(\mathrm{OF}(\mathrm{t}))$. Since there are no

data on these parameters in Portugal, values for age-specific breathing rates, age-specific body weights and PM10 loael reported by [31] wereused (Table 1 ).

To assess the risks associated with inhalation exposure to PAHs, the concept of toxicity equivalency factors (TEF) $[5,32]$ that estimates carcinogenicity relatively to benzo[a]pyrene was used. The corre- sponding lifetime lung cancer risks were also estimated [33].

\subsection{Statistical methods}

For the data treatment, the Student's $t$-test was applied to de- termine the statistical significance ( $P$ b 0.05, two tailed) of the dif- ferences between the means.

3. Results and discussion

\subsection{Air pollution in Oporto Metropolitan Area}

The annual means of pollutants in Oporto MA between 2002 and 2008 are shown in Fig. 2. As it can be seen the annual levels of $\mathrm{CO}$ slightly decreased whereas the means of NOx and $\mathrm{NO}_{2}$ have not changed significantly during that period. Despite that, the Member States of European Union (including Portugal) still have difficulty to

Table 1

Body weight, breathing rates and lowest observed adverse health effect levels (loael)

morbidity values for PM10 [31].

Body weight Inhalation volume Loael

for morbidity ( $\mathrm{kg}) \quad\left(\mathrm{m}^{3}\right.$ day $\left.^{-1}\right)$

$$
\left(\mu \mathrm{kg}^{-1} \mathrm{day}^{-1}\right)
$$

\begin{tabular}{|c|c|c|}
\hline New born & 0.8 & 14.7 \\
\hline Children (1 year) 10 & 3.8 & 20.9 \\
\hline Children (8-10 years) & 3010.0 & 27.5 \\
\hline Adult & 20.0 & 15.7 \\
\hline
\end{tabular}




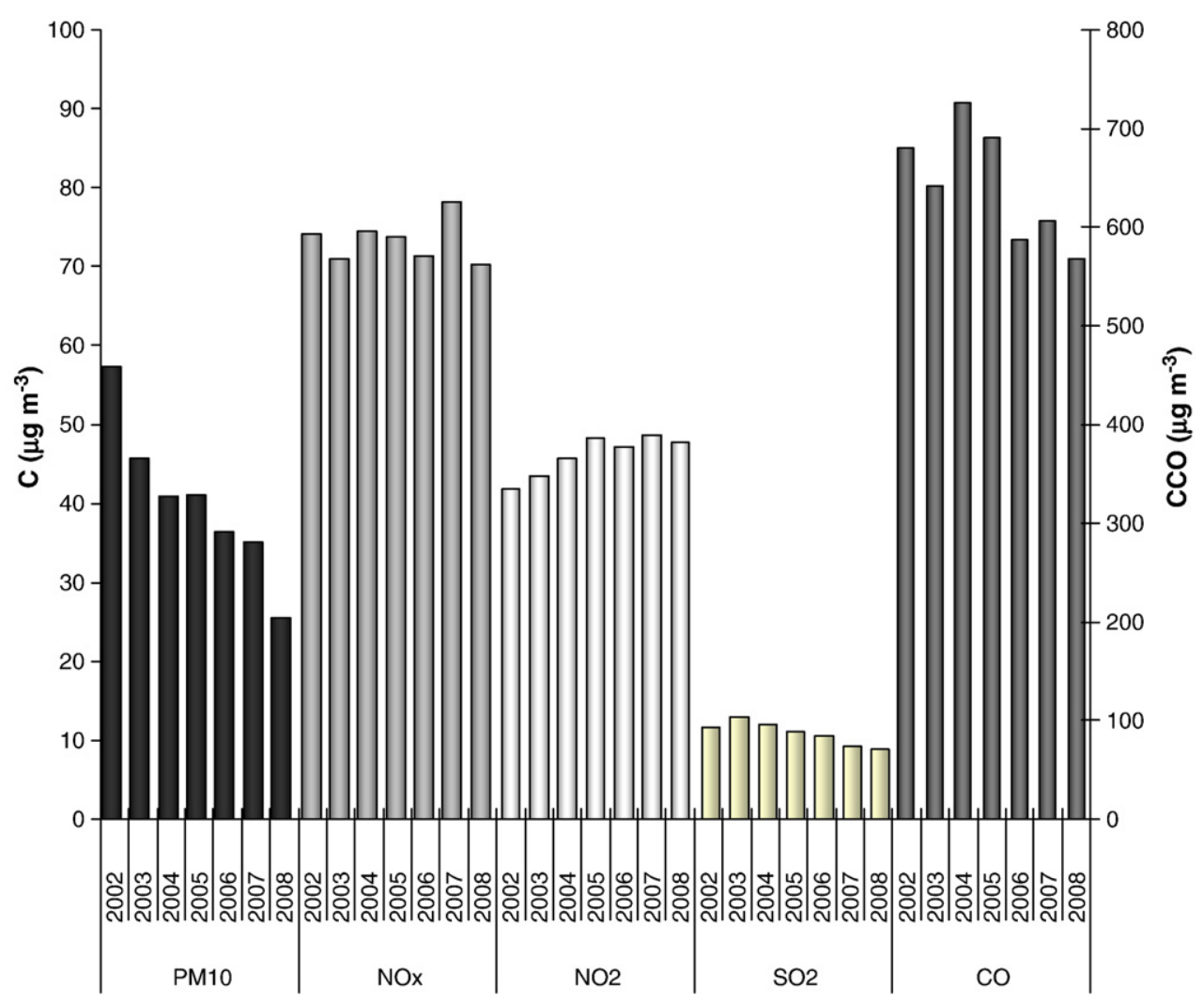

Fig. 2. Annual levels of traffic pollutants in Oporto Metropolitan Area.

comply the legislative emission ceilings of nitrogen oxides [34], mainly due to the fact that the demand for road transport has been growing much faster than it was anticipated [35]; traffic emissions have remained the single main source of nitrogen oxides and carbon monoxide [3]. The results in Fig. 2 also show that the levels of $\mathrm{SO}_{2}$ have been decreasing during the last years. Atmospheric $\mathrm{SO}_{2}$ gasses mostly result from fossil fuels (coal and oil) combustions for industrial and domestic activities and the implementation of environmental legislation has led to the reduction of these emissions in the urban environments over the past years [23]. However, $\mathrm{SO}_{2}$ emissions are also produced by diesel combustion engines [36] and in that regard they are especially relevant, considering the importance of air pollution from vehicular traffic and its health-significant for public health [1]. Regarding PM10 Fig. 2 clearly shows that since 2002 [37]

PM10 levels have also decreased; between 2002 and 2008, PM10 annual concentrations lowered approximately by $30 \mu \mathrm{g}$ $\mathrm{m}^{-3}$. As it can be also seen in Fig. 2, the annual standard value $\left(40 \mathrm{\mu g} \mathrm{m}^{-3}\right)$ [38] has not been exceeded in Oporto MA since 2006. Nevertheless, the daily

limit of $50 \mu \mathrm{g} \mathrm{m}^{-3}$ (cannot be exceeded more than 35 times per year) [38], was exceeded 73 times in 2008 in Oporto MA [39]; in that year Oporto was the Portuguese region with the highest frequency of exceedances.

During the autumn-winter sampling period, the daily means of collected PM10 and PM2.5 ranged, respectively, from 16.1 to $70.9 \mathrm{\mu g} \mathrm{m}^{-3}$ (average of $36.2 \pm 15.1 \mathrm{\mu g} \mathrm{m}^{-3}$ ) and from 6.6 to $59.9 \mathrm{\mu g} \mathrm{m}^{-3}$ (average of

$25.2 \pm 13.8 \mu \mathrm{g} \mathrm{m}^{-3}$ ). These daily means were in accordance with the

ones reported for the respective sampling period for Oporto MA by Portuguese Environmental Agency [37]. The statistical analysis of the results indicated that PM10 and PM2.5 means were significantly different. On average, $\mathrm{PM} 2.5$ fraction accounted for approximately $69 \%$ of PM 10 . In general the obtained results were in agreement with other aerosol studies performed in Oporto MA $[40,41]$ and in other European and non- European urban environments $[33,42]$. 
The concentrations of the studied PAHs are summarized in Table 2, which presents the particulate-bound, gaseous and total (i.e. sum of PAHs in PM10 and gas phase) levels of the 18 quantified compounds. As it can be observed, the total concentrations of all $18 \mathrm{PAHs}$ (i.e. $\mathrm{PPAHs}$ )

ranged from 16.8 to $149 \mathrm{ng} \mathrm{m}^{-3}$ with a mean of $69.9 \pm 39.7$ $n g \mathrm{~m}^{-3}$.

Phenanthrene was the most abundant PAH and accounted for $27 \%$ of total $\Sigma \mathrm{PAHs}$, being in agreement with other related studies $[43,44]$ that also showed that high abundance of phenanthrene was characteristic for traffic emissions. PAHs with 3-4 rings, typically associated with emissions from diesel cars [45-47] were also significantly abundant; namely, acenaphthylene, pyrene, fluorene and fluoranthene, accounted, respectively, for $11 \%, 9.5 \%, 9.4 \%$ and $8.6 \%$ of the total quantified PAHs. The PAHs with 3-4 rings accounted for $75 \%$ of the total $\Sigma$ PAHs.

The results in Table 2 also show that $70 \%$ of the total $\Sigma$ PAHs existed

in the gas phase. These results emphasize the importance of gaseous PAHs assessment which is frequently omitted, although Chirico et al. [48] reported that in a close proximity to a major traffic thoroughfare situated $15 \mathrm{~km}$ outside Rome, 99\% of traffic-related PAHs existed in the gas phase.

Particulate-bound PAHs accounted for $30 \%$ of total $\Sigma$ PAHs. In agreement with other studies particulate-bound PAHs were predom- inantly present in PM2.5 fraction $[29,49]$; on average, $92 \%$ of particulate PAHs was associated with PM2.5 and $8 \%$ of PAH content was present in particles bigger than $2.5 \mu \mathrm{m}$ (i.e. PM2.5-10). These findings are especially healthrelevant because fine particles cause many adverse health effects including cardiopulmonary diseases and lung cancer; PAHs associated with these particles may contribute to (or eventually even enhance) these health effects. Benzo[b $[j]$ fluoranthene were the most abundant particulate-bound PAHs (approximately 23\% of particulate $\Sigma$ PAHs.) with concentrations reach-

ing up to 9.96 and $9.56 \mathrm{ng} \mathrm{m}^{-3}$ for PM10 and PM2.5, respectively.

In agreement with other relevant studies, PAHs with 5-6 rings dominated the particulate phase $[29,49,50]$. Among the most abundant 
Table 2

Concentrations (mean and range) of PAHs in particulate phase (PM10 and PM2.5), gas phase, and total in air (ng $\mathrm{m}^{-3}$ ).

\begin{tabular}{|c|c|c|c|c|c|c|c|c|c|}
\hline & & \multicolumn{3}{|c|}{ Particulate phase } & & \multicolumn{2}{|c|}{ Gas phase } & \multicolumn{2}{|c|}{ Total air } \\
\hline & & \multicolumn{2}{|l|}{ PM10 } & \multicolumn{2}{|l|}{ PM2.5 } & & & & \\
\hline $\begin{array}{l}\text { Nanhthalene } \\
\text { Acenanhthvlene } \\
\text { Acenaphthene }\end{array}$ & $\begin{array}{l}2 \\
3 \\
3\end{array}$ & $\begin{array}{l}\text { n.1.19 } \\
\text { n.d. } \\
\text { O.0057 }\end{array}$ & $\begin{array}{l}\text { n d- } \\
\text { n.d. } \\
\text { n.d- }\end{array}$ & $\begin{array}{l}0.115 \\
0.0036\end{array}$ & $\begin{array}{l}\text { n d - } \\
\text { n.d. } \\
\text { n.:- }\end{array}$ & $\begin{array}{l}2.50 \\
7.84\end{array}$ & $\begin{array}{l}\text { n d -14 } 7 \\
\text { 8.180 }\end{array}$ & $\begin{array}{l}267 \\
7.84\end{array}$ & $\begin{array}{l}\text { n d -14 } 7 \\
\text { 8.180 }\end{array}$ \\
\hline
\end{tabular}

a n.d. - not

ones were, by descending order, benzo[ghi]perylene $(11 \%$ of particulate $\quad$ SPAHs), benzo[a]pyrene (10\%), dibenz[a,h]anthracene (9\%), and ideno [1,2,3-cd]pyrene (8\%). Out of these, benzo[a]pyrene is the known carcinogen to human [7] whereas dibenz[a,h]anthracene and indeno [1,2,3cd]pyrene, but also benz[a]anthracene, chrysene, benzo[b+j] fluoranthene, benzo[k]fluoranthene, dibenzo[a,I]pyrene are consideredas possible/probable carcinogen [7]. Whereas these nine carcinogens existed entirely in the particulate phase accounting for $64 \%$ of $\Sigma \mathrm{PAHs}$, naphthalene, another carcinogenic $\mathrm{PAH}$ [6] was present almost entirely in the gas phase (97\%) where it accounted for $7 \%$ of the gaseous $\Sigma$ PAHs.

\subsection{Health risk assessments of PM and PAHs}

Dose rates and the values of potential health risks associated with exposure to PM10 were calculated (evaluation of PM2.5 health risks was not performed because PM2.5 loael were not available in the literature) considering that people spend about $20 \%$ of their time outdoors [19]. Results are shown in Table 3. As it can be seen new- borns, 1 year old children and adults showed similar values of health risks, whereas children with the age between eight to ten years exhibited the lowest potential risks. Values indicate that no significant risks exist through PM10 inhalation for the several population groups. Since PM 2.5 represent the PM fraction which is the most

relevant (due to the smaller particle size PM2.5 penetrates in to the

deeper regions of lungs and into the alveoli), loael values for $\mathrm{PM} 2.5$ pyrene appeared in air samples in very low concentrations (less than $0.2 \%$ ) (Table 2) but due to its high TEF (100) it was the second largest contributor to $\Sigma$ TEF-PAHs with a mean of $43 \%$. Dibenz[a,h]anthracene with TEF of 5 was then the largest contributor to ETEF-PAHs in air, contributing 44\%. These results confirm and emphasize the impor-tance of the analysis and evaluation of these two potent carcinogens that are being currently discussed as possible surrogate compounds for PAH mixtures from various environments [11]. Furthermore, the associated health risks of PAHs and PM are expected to be higher than those predicted by an additive model of these two contributors.

The values of ITEF-PAHs were used to estimate the corresponding lifetime lung cancer risks for exposed groups. Regarding the lung cancer risk via the inhalation route, the World Health Organization suggested the unit risk of $8.7 \times$ $10^{-5}$ (ng m $\left.^{-3}\right)^{-1}$ for lifetime (70 years) PAHs exposure [33]. The determined lifetime lung cancer risk was $1.9 \times 10^{-3}$. It is important to point out that the estimated value considerably exceeded the health-based guideline level of $10^{-5}$ (approximately 190 times higher) [52], showing that despite the

Table 4

TEF-adjusted mean concentrations of PAHs in particulate phase (PM10 and PM2.5), gas phase, and the total in air (pg TEF $^{\mathrm{a}}$ Particulate phaseGas Total phase

PM10 PM2.5 
would be precious to refine this health risk assessment.

As scientific community has recognized that there is no identifiable threshold below which PAHs do not pose risk to humans, genotoxic and carcinogenıc rAHs require the tullest possible risk assessment. In this work, 'IEF' approach was applied to calculate the TEF-adjusted concentrations (based on benzo[a]pyrene) of carcinogenic PAHs [11,51]. The results are shown in Table 4. Dibenzo[a,l]

Table 3

\begin{tabular}{|c|c|c|c|c|}
\hline \multirow[t]{2}{*}{ Age category } & \multicolumn{2}{|c|}{ Dose $\left(\mu \mathrm{g} \mathrm{kg}^{-1}\right)$} & \multicolumn{2}{|c|}{ Health risks } \\
\hline & viean & Kange & viean & kange \\
\hline New-borns & 1.93 & $0.858-3.78$ & 0.131 & $0.0580-0.257$ \\
\hline Children (1 year) & 2.75 & $1.22-5.39$ & 0.132 & $0.0585-0.268$ \\
\hline Children ( $8-10$ years) & 2.41 & $1.07-4.73$ & 0.0878 & $0.0390-0.172$ \\
\hline Adults & 2.07 & \multicolumn{2}{|c|}{$0.920-4.05$} & 0.132 \\
\hline
\end{tabular}

Naphthalene

Acenaphthylene

Acenaphthene

Fluorene

Phenanthrene

Anthracene

Fluoranthene

Pyrene

Benz[a]anthracene

Chrysene

Benzo[b $+j]$ fluoranthene

Benzo[k]fluoranthene

Benzo[a]pyrene

Dibenzo[a,l]pyrene

Dibenz[a,h]anthracene

Benzo[ghi]perylene

Indeno[1,2,3-cd]pyrene

$\begin{array}{ll}0.001 & 0.119 \\ 0.001 & - \\ 0.001 & 0.00578 \\ 0.001 & 0.0582 \\ 0.001 & 0.802 \\ 0.01 & 5.04 \\ 0.001 & 1.16 \\ 0.001 & 1.56 \\ 0.1 & 109 \\ 0.1 & 16.3 \\ 0.1 & 485 \\ 0.1 & 99.4 \\ 1 & 2020 \\ 100^{\mathrm{b}} & 9200 \\ 5 & 9410 \\ 0.01 & 22.4 \\ 0.1 & 179\end{array}$

0.115

3.50

3.62

.84

6.55

18.9

18.9

6.05

6.64

115.

16.3

485

99.4

2020

9200

9410

22.4

179

a [51].

b [11]. 

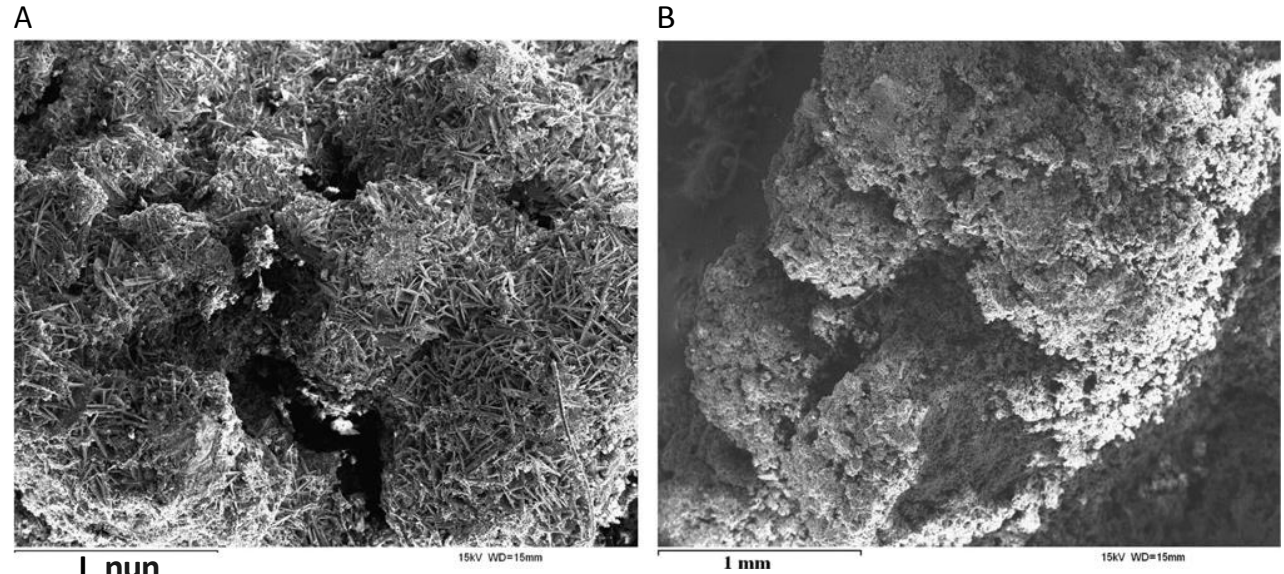

C
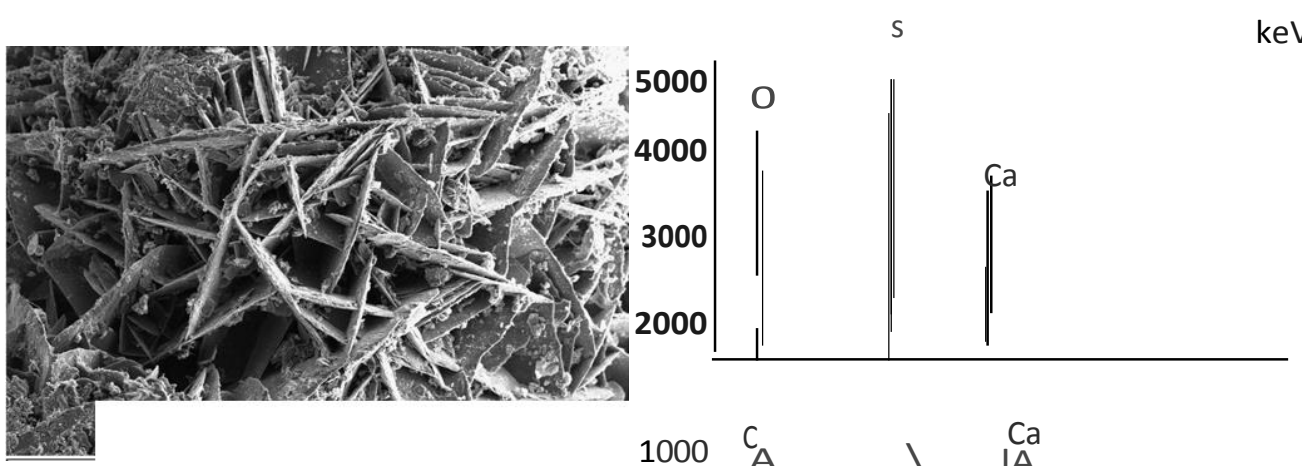

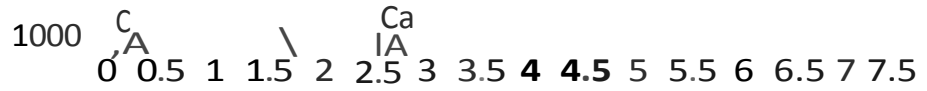
0

F"1Scele 5819 cts Cursor:-0.193 (0 cts) keV

400 um

D
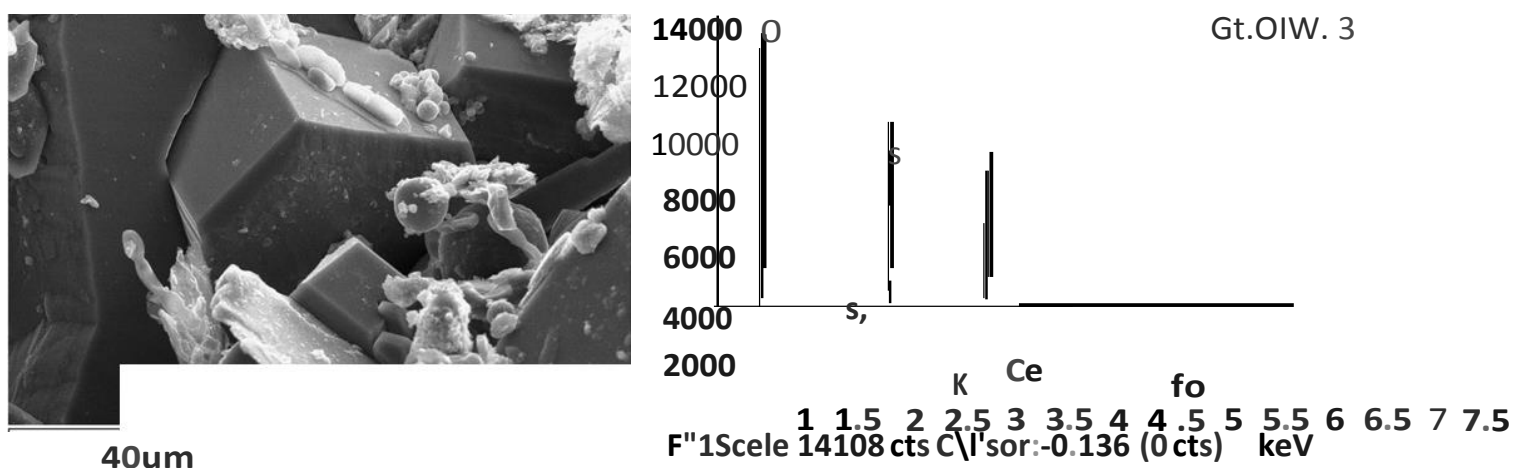

E

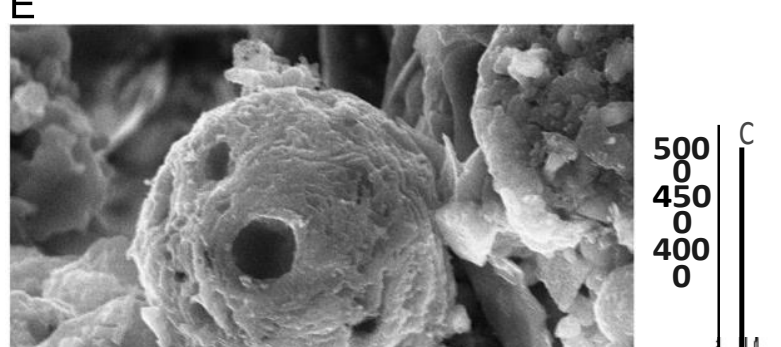




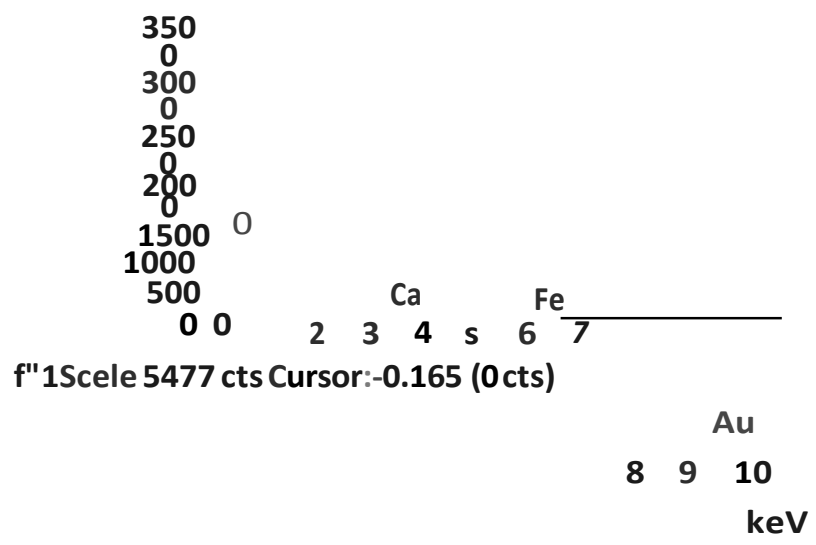

Fig. 3. SEM images and EDX spectra of black crust samples from Monastety of Serra do Pilar: (A and B) general image of crusts: (C) gypsum: (D) gypsum with impurities: and (E) flyash with porous morphology. 

Table 5

The levels of $18 \mathrm{PAHs}$ in black crusts $\left(\mathrm{ng} \mathrm{g}^{-1}\right)$.

\begin{tabular}{|c|c|c|}
\hline Compound & $\begin{array}{l}\text { Mean } \\
\left.\text { Range-1) } \text { (ng }^{-1}\right)^{-1}\end{array}$ & (ng \\
\hline $\begin{array}{l}\text { Naphthalene } \\
19.2\end{array}$ & 7.07 & $1.88-$ \\
\hline Acenaphthylene & n.d. a & n.d. \\
\hline Acenaphthene & n.d. & n.d. \\
\hline $\begin{array}{l}\text { Fluorene } \\
20.6\end{array}$ & 6.05 & $1.48-$ \\
\hline Phenanthrene & 150 & $49.5-431$ \\
\hline $\begin{array}{l}\text { Anthracene } \\
18.8\end{array}$ & 7.41 & $2.92-$ \\
\hline Fluoranthene & 159 & $68.3-388$ \\
\hline Pyrene & 122 & $45.2-287$ \\
\hline $\begin{array}{l}\text { Benz[a]anthracene } \\
91.9\end{array}$ & 36.5 & $14.0-$ \\
\hline Chrysene & 59.4 & $206-130$ \\
\hline Benzo[b+j]fluoranthene & 149 & $62.1-343$ \\
\hline $\begin{array}{l}\text { Benzo[k]fluoranthene } \\
67.8\end{array}$ & 29.7 & $12.8-$ \\
\hline Benzo[a]pyrene & 49.9 & $19.8-113$ \\
\hline $\begin{array}{l}\text { Dibenzo[a,I]pyrene } \\
17.7\end{array}$ & 7.60 & $3.42-$ \\
\hline Dibenz[a,h]anthracene & 78.3 & $34.0-169$ \\
\hline Benzo[ghi]perylene & 59.0 & $24.8-128$ \\
\hline Indeno[1,2,3-cd]pyrene & 54.4 & 22.6-119 \\
\hline $\begin{array}{l}\sum \mathrm{PAHs} \\
2320\end{array}$ & 975 & 409- \\
\hline
\end{tabular}

a n.d. - not detected.

average limited period of time spent outdoors (20\%), PAHs from outdoor sources, especially traffic emissions, represent serious risks to human health.

\subsection{Impact of air pollution on stone decay of historical façades}

Fig. 3 shows the SEM images of the black crust samples from Monastery Serra do Pilar. The black crusts were between 3 and $7 \mathrm{~mm}$ thick and with dendritic surface. Both FTIR (results not shown) and EDX analyses revealed that black crusts were mostly composed of gypsum ( $\mathrm{CaSO}_{4} \cdot 2 \mathrm{H}_{2} \mathrm{O}$; Fig. $3 \mathrm{C}$ ), with impurities mostly of silicon (Si), aluminum (AI), potassium (K) and sodium ( $\mathrm{Na}$ ) (Fig. 3D), showing the following abundances: $\mathrm{CaO}$ (19.13-23.57\%), SO3 (16.95-18.19\%), $\mathrm{SiO}_{2}$ (5.54$20.45 \%), \mathrm{Al}_{2} \mathrm{O} 3$ (2.41-8.15\%), and $\mathrm{K}_{2} \mathrm{O}(0.75-2.98 \%)$. The subsoil of Oporto region consists of granite and this material has been

used for the construction of most of the historical monuments
Table 6

Diagnostic ratios of PAHs emitted by traffic.

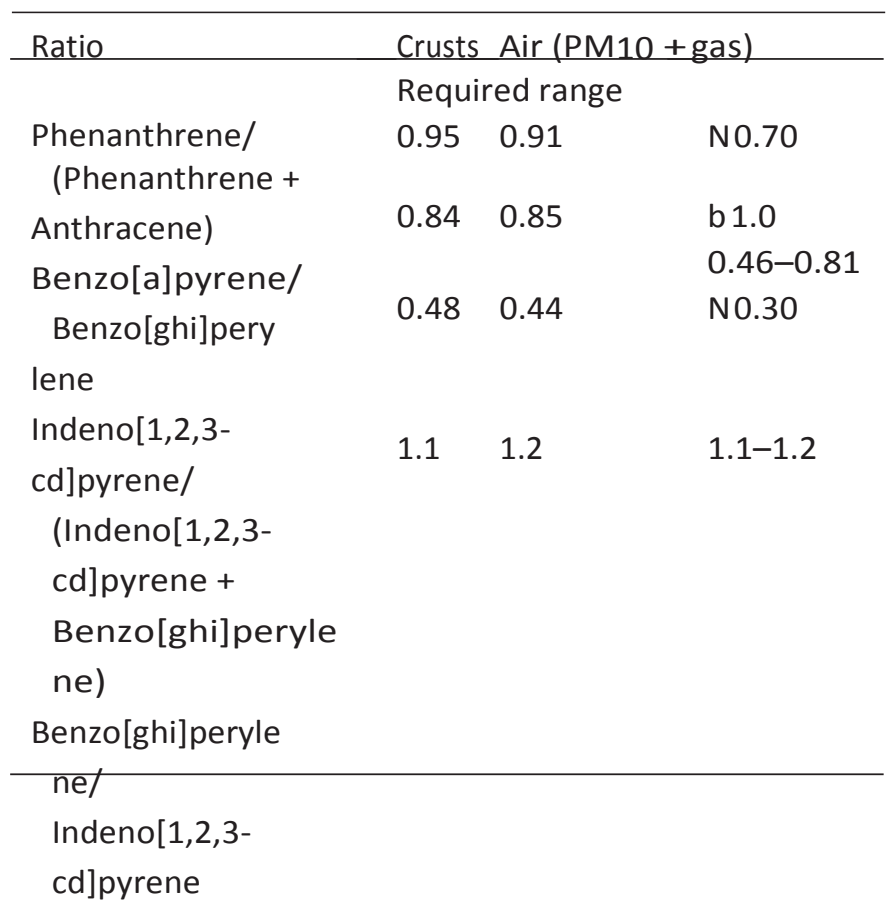

in this region [20]. Essentially, the Oporto granite is composed of minerals such as quartz, microcline, albite, muscovite, and biotite, being rich in $\mathrm{Si}, \mathrm{Al}, \mathrm{K}$, and $\mathrm{Na}$ with the following abundances: $\mathrm{SiO}_{2}$ (72.58-73.50\%), $\mathrm{Al}_{2} \mathrm{O} 3$ (14.21-15.03\%), K2O (4.44-4.64\%) and $\mathrm{Na2O}(3.66-3.77 \%)$.

Thus, it is possible to suggest that impurities of these four elements ( $\mathrm{Si}, \mathrm{Al}, \mathrm{K}$, and $\mathrm{Na}$ ) in black crusts originated probably from this source. Concerning gypsum formation, when black crusts are formed on monuments built from calcium carbonate rich rocks (limestone, marble, and carbonate sandstone), part of the calcium ion $\left(\mathrm{Ca}^{2+}\right)$ is typically supplied by the surface stone itself, whereas sulfate ion 
The levels of 18 PAHs in black crusts were also determined and the

obtained PAH concentrations are presented in Table 5. The results showed that PAHs with 4 and 5 rings, namely fluoranthene (16\% of $\Sigma$ PAHs) and benzo[b+j]fluoranthene (15\%) were among the mostabundant compounds, being followed by pyrene (13\%) and dibenz[a, h]anthracene (8\%). In total, PAHs with 4 rings accounted for approximately $40 \%$ of $\Sigma$ PAHs whereas $45 \%$ of $\Sigma$ PAHs were compoundswith 5-6 rings; these findings were in agreement with a previous study published by Martínez-Arkarazo et al. [21] concerning a non-granitic palace house situated in the metropolitan area of Bilbao (Spain). PAHs with 2-3 rings accounted in general for less than $1 \%$ of $\Sigma$ PAHs. These significantly lower contributions of 2-3 rings $\mathrm{PAHs}$ are related with their lower molecular weights and higher volatility that justify their predominant presence in the gaseous phase. However, for phenanthrene, also a compound with 3 rings, different results were observed. Its concentrations in crusts reached

up to $431 \mathrm{ng}^{-1}$ and phenanthrene accounted $4 \mathrm{SO}_{2}$ enisvitypinadiyt filom the rain water due to the

pollution. However, calcium content $(\mathrm{CaO})$ in Oporto granite is very low $(0.51-0.58 \%)$ and due to the natural weathering processes it is even lower [20]. Rain water chemical analysis obtained in Oporto

$5 \$$ owed that $\left(\mathrm{Ca}^{2+}\right)$ and 2 aritio is $1: 1$. As a result whenever

water evaporates in sheltered areas of historical monuments, gypsum crystallizes originating black crusts that become thicker in every precipitation episode [53]. These conditions then cause continuous build-up of black crusts on the historical monuments due to environmental pollution.

Regarding the last group of the most abundant particles identified in black crusts, it was constituted of fly ashes (Fig. 3E). These particles were mainly composed by carbon with some impurities of S, Si, Al, and Fe. The porous morphology of these particles suggests origin mostly from combustion sources $[20,54,55]$. In Oporto MA the most significant sources of carbonaceous particulates are emissions from traffic [56] and from a power plant situated nearby [57]; the contribution from other sources is considerably less significant [56,57].

of indeno[1,2,3-cd]pyrene/(indeno[1,2,3-cd]pyrene+ benzo[ghi]per-ylene) higher than 0.30 indicates significant emissions from diesel vehicles [45]; these emissions are also indicated by benzo[ghi] perylene/indeno[1,2,3-cd]pyrene ratio with values in the range be- tween 1.1 and 1.2 (Ohura et al., 2004) or by benzo[a]pyrene/benzo [ghi]perylene ratio with values between 0.46 and 0.81 [58]. As it can be clearly seen in Table 6, all ratio values of black crusts were within the required range to diagnose that the deposited $\mathrm{PAHs}$ originated from traffic emissions, and particularly those from diesel vehicles. These results are in general agreement with EEA report which indicated that since 1990 the contribution of emissions from diesel- fuelled vehicles to road transport ones significantly increased [26]. The diagnostic ratios obtained for PAHs in air (Table 6) corroborat approximately for $15 \%$ of $\Sigma \mathrm{PAHs}$, thus being the second most abundant PAH in black crusts; it should be remarked that phenanthrene, mainly emitted by traffic emissions $[43,44]$, was the most abundant PAH in air (27\% of $\Sigma$ PAHs; Table 2 ). Considering the high levels of phenanthrene both in air and in black crusts, it is possible to suggest that traffic emissions clearly influenced compo- sition and the growth of black crusts. Furthermore, from the health point of view, it is also important to point out that the existence of considerable levels of PAHs deposited and accumulated in buildings and monuments could lead to higher human exposures and cause additional risks for human health. This knowledge is especially important to define appropriate safety equipments and procedures during building cleaning and restoration processes.

The results in Table 5 also show that, in black crusts, PAHs usually considered as traffic emissions indicators $[44,46]$ are among the most abundant: fluoranthene, phenanthrene, benzo[b + j]fluoranthene, pyrene, and dibenz[a,h]anthracene. These results suggest that PAHs in crust originated mostly from

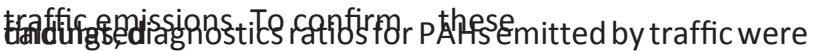

for compounds both in crusts and in air (Table 6). Typically the value of phenanthrene/(phenanthrene+ anthracene) ratio higher than 0.70 and of benzo[a]pyrene/benzo[ghi]perylene ratio lower than 1.0 madiieate that PAHs are emitted by traffic $[45,58]$; specifically, a 


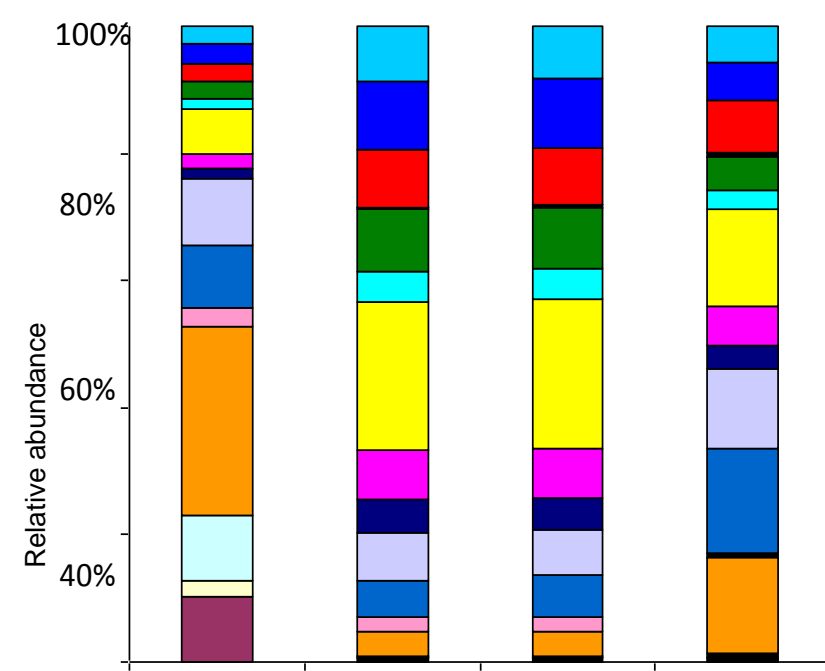

$20 \%$

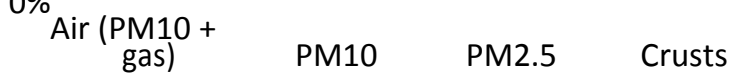

Indeno[1,2,3-

acd]pyrene

Benzo[ghi]perylene

口 Dibenz[a,h]anthrac

$\square$ ene

- Dibenzo[a,I]pyrene

Benzo[a]pyrene

Benzo[k]fluoranthe

$\square$ ne

$\square$ Benzo[b+j]fluorant

$\square$ hene Chrysene

Benz[a]anthracene

Pyrene

Fluoranthene

Anthracene

Phenanthrene

Fluorene

Anthracene

Acenaphthylen

e Naphthalene

Fig. 4. Relative abundances (\%) of 18 PAHs in air, PM10, PM2.5, and in black crusts of Monastery of Serra do Pilar.

the previous findings, thus confirming that traffic emissions were the major source of PAHs.

In order to further evaluate the influence of traffic emissions on deposition of PAHs on surfaces of historical monuments, Fig. 4 presents the relative abundances of $18 \mathrm{PAHs}$ in air (i.e. sum of PAHs in gaseous and particulate phase), in PM10, PM2.5, and black crusts. The composition profiles of PAHs in the PM10, PM2.5, and crusts were very similar, showing that air quality, or more specifically air pollution, may contribute to potential deterioration of buildings and historical monuments. These findings are in general agreement with other studies $[15,59]$ that concluded that deposition of atmospheric pollutants, namely of particulate matter (to which PAHs are bound), was a significant cause for monument and building deterioration. Nevertheless, it is important to point out that phenanthrene that was in both crust and air among the most abundant PAHs (Fig. 4), existed predominantly in the gas phase (96\%, Table 2$)$, thus revealing the importance of also gaseous pollutants for buildings and historical monuments deterioration.

\section{Conclusions}

Between 2002 and 2008 the annual levels of CO, SO2, and PM10 decreased in Oporto MA whereas the levels of NOx and NO2 have not changed significantly during that period. As these pollutants may promote serious problems, in order to protect public health it is fundamental to continue with efforts reducing emissions of these pollutants, mainly related to vehicular transport.

Traffic emissions were the main source of PAHs in air of the respective metropolitan area. The mean concentration of $18 \mathrm{PAHs}$ in air was $69.9 \pm$ $39.7 \mathrm{ng} \mathrm{m}^{-3}$ with $3-4$ rings $\mathrm{PAHs}$ accounting for $75 \%$ of the total $\Sigma \mathrm{PAHs}$. The health risk analysis of PAHs in air showed that the estimated values of lifetime lung cancer risks considerably exceeded the health-based guideline level. Furthermore, the results showed that evaluation of benzo[a]pyrene (regarded as a marker of the genotoxic and carcinogenic PAHs $[9,60])$ alone would probably underestimate the carcinogenic potential of the studied PAH mixtures.

Analytical results also confirm that historical monuments in urban areas act as passive repositories for air pollutants present in the surrounding atmosphere. FTIR and SEM-EDX analyses showed that gypsum was the most important constituent of black crusts of the Monastery of Serra do Pilar, UNESCO World Cultural Heritage monument. The total concentration of $18 \mathrm{PAHs}$ in black crusts was $975 \pm 460 \mathrm{ng} \mathrm{g}^{-1} ; 4-6$ rings compounds accounted approximately for 
$85 \%$ of $\Sigma$ PAHs. The diagnostic ratios confirmed that traffic emissions were the major source of PAHs in black crusts; $\mathrm{PAH}$ composition profiles were very similar for crusts and PM10 and PM2.5. The existence of the considerable levels of PAHs deposited in buildings and monuments may lead to higher human exposures thus representing additional risks for human health.

\section{Acknowledgments}

The authors would like to thank to Fundação Calouste Gulbenkian and to Fundação para Ciência e Tecnologia for the financial support of this work (SFRH/BD/23605/2005 and SFRH/BPD/65722/2009). The authors are also grateful to Márcio Vieira Madureira, MSc. for providing photographical material.

\section{References}

[1] European Environment Agency (EEA), Transport and Environment in Europe, EEA Briefing 03/2004, EEA, Copenhagen, 2004.

[2] G. Muránszky, M. Óvári, I. Virág, P. Csiba, R. Dobai, G. Záray, Chemical characterization of PM10 fractions of urban aerosol, Microchem. J. 98 (2011) 1-10.

[3] European Environmental Agency (EEA), Annual European Community LRTAP Convention Emissions Inventory Report 1990-2006, EEA Technical Report No. 7, EEA, Copenhagen, 2008.

[4] N. Kunzli, R. Kaiser, S. Medina, Public-health impact of outdoor and traffic-related air pollution: a European assessment, Lancet 356 (2000) 795-801.

[5] World Health Organization (WHO), Environmental Health Criteria 202: Selected Non-Heterocyclic Polycyclic Aromatic Hydrocarbons, International Programme on Chemical Safety, World Health Organisation, Geneva, 1998.

[6] IARC, Some traditional herbal medicines, some mycotoxins, naphthalene and styrene, IARC Monogr. Eval. Carcinog. Risk. Hum. 82 (2002) 367.

[7] IARC, Some non-heterocyclic polycyclic aromatic hydrocarbons and some related exposures, IARC Monogr, Eval. Carcinog. Risk. Hum. 92 (2010) 773.

[8] T. Shibamoto, Chromatographic Analysis of Environmental and Food Toxicants, first ed. Marcel Dekker, INC., New York, 1998.

[9] European Union (EU), Directive 2004/107/EC of the European Parliament and of the
Council relating to arsenic, cadmium, mercury, nickel and polycyclic aromatic hydrocarbons in ambient air, Official J. European Union L23 (2005) 3-16.

[10] M. Pufelete, J. Battershill, A. Boobis, R. Fielder, Approaches to carcinogenic risk assessment for polycyclic aromatic hydrocarbon: a UK perspective, Regul. Toxicol. Pharm. 40 (2004) 54-56.

[11] K.W. Okona-Mensah, J. Battershill, A. Boobis, R. Fielder, An approach to investigating the importance of high potency polycyclic aromatic hydrocarbons (PAHs) in the induction of lung cancer by air pollution, Food Chem. Toxicol. 43 (2005) 1103-1116.

[12] C. Bergvall, R. Westerholm, Identification and determination of highly carcino- genic dibenzopyrene isomers in air particulate samples from a street canyon, a rooftop, and a subway station in Stockholm, Environ. Sci. Technol. 41 (2007) 731-737. 
[13] G. Gill, C. Pignata, T. Schilirò, R. Bono, A. La Rosa, D. Traversi, The mutagenic hazards of environmental PM2.5 in Turin, Environ. Res. 103 (2007) 168-175.

[14] Y. Kameda, J. Shirai, T. Komai, J. Nakanishi, S. Masunaga, Atmospheric polycyclic aromatic hydrocarbons: size distribution, estimation of their risks and their deposition to the human respiratory tract, Sci. Total Environ. 340 (2005) 71-80.

[15] N. Marioni, M.P. Birelli, C. Rostagno, A. Pavese, The effects of atmospheric multipollutants on modern concrete, Atmos. Environ. 37 (2003) 4701-4712.

[16] R.M. Esbert, F. Díaz-Pache, C.M. Grossi, F.J. Alonso, J. Ordaz, Airborne particulate matter around the Cathedral of Burgos (Castilla y León, Spain), Atmos. Environ. 35 (2001) 441-452.

[17] C. Sabbioni, G. Zappia, C. Riontino, M.T. Binco-Varela, J. Aguilera, F. Puertas, K. Van Balen, E.F. Toumbakari, Atmospheric deterioration of ancient and modern hydraulic mortars Atmos, Environ. 35 (2001) 539-548.

[18] M. Gaviño, B. Hermosin, V. Vergès-Belmin, W. Nowik, W. Saiz-Jimenez, Composition of the black crust from the Saint Denis Basilica, France, as revealed by gas chromatography-mass spectrometry, J. Sep. Sci. 27 (2004) 513-523.

[19] M.R. Mannino, S. Orecchio, Polycyclic aromatic hydrocarbons (PAHs) in indoor dust matter of Palermo (Italy) area: Extraction, GC-MS analysis, distribution and sources, Atmos. Environ. 42 (2008) 1801-1817.

[20] A. Begonha, Meteorização do granito e deterioração da pedra em monumentos e edifícios da cidade do Porto, FEUP-Edições-Colecção Monografias, first ed, Porto, 2001.

[21] I. Martínez-Arkarazo, M. Angulo, L. Bartolomé, N. Etxebarria, M.A. Olazaba, J.M. Madariaga, An integrated analytical approach to diagnose the conservation state of building materials of a palace house in the metropolitan Bilbao (Basque Country, North of Spain), Anal. Chim. Acta 584 (2007) 350-359.

[22] M.L. Real, M.J. Távora, M.I. Pinto Osório, F.F. Teixeira, Escavações arqueológicas no Morro da Sé, Cultural Bulletin of Oporto Municipal Hall 3/4 (in Portuguese), Municipal Hall, Porto, 1985-86.

[23] M.C. Pereira, R.C. Santos, M.C.M. Alvim-Ferraz, Air quality improvements using European environmental policies: a case study of $\mathrm{SO} 2$ in coastal region in Portugal, J. Toxicol. Env. Health A 70 (2007) 347-351.

[24] M.C.M. Alvim-Ferraz, M.C. Pereira, J.M. Ferraz, A.M.C. Almeida Test, European directives for air quality: analysis of the new limits in comparison with asthmatic symptoms in children living in Oporto metropolitan area, Portugal, Hum. Ecol. Risk Assess. 11 (2005) 607-616.

[25] M.C. Pereira, M.C.M. Alvim-Ferraz, R.C. Santos, Relevant aspects of air quality in Oporto (Portugal): PM10 and O3, Environ. Monit. Assess. 101 (2005) 203221.
[26] European Environment Agency (EEA), Impact of Selected Policy Measures on Europe's Air Quality, EEA Technical Report No. 8, EEA, Copenhagen, 2010.

[27] European Environment Agency (EEA), Air Quality in Europe: State and Trends 1990-99, EEA Topic report 4/2002, EEA, Copenhagen, 2003.

[28] M. Tsapakis, E.G. Stephanou, Collection of gas and particle semi-volatile organic compounds: use of an oxidant denuder to minimize polycyclic aromatic hydrocarbons degradation during high-volume air sampling, Atmos. Environ. 37 (2003) 4935-4944.

[29] D. Castro, K. Slezakova, M.T. Oliva-Teles, C. Delerue-Matos, M.C. Alvim-Ferraz, S. Morais, M.C. Pereira, Analysis of polycyclic aromatic hydrocarbons in atmospheric particulate samples by microwave-assisted extraction and liquid chromatogra- phy, J. Sep. Sci. 32 (2009) 501-510.

[30] J.N. Miller, J.C. Miller, Statistics for Analytical Chemistry, Pearson Education Ltd., Harlow, 2000.

[31] M. Kalaiarasan, R. Balasubramanian, K.W.D. Cheong, K.W. Tham, Traffic generated airborne particles in naturally ventilated multi-storey residential buildings of Singapore: vertical distribution and potential health risks, Build. Environ. 44 (2009) 1493-1500.

[32] U.S. Environmental Protection Agency (USEPA), Guidelines for Carcinogen Risk Assessment, Federal Register 51(185):33992-34003, EPA/630/R-00/004, U.S Government Printing Office, Washington DC, 1986.

[33] T. Ohura, T. Amagai, T. Sugiyama, M. Fusaya, H. Matsushita, Characteristics of particle matter and associated polycyclic aromatic hydrocarbons in indoor and outdoor air in two cities in Shizuoka, Japan, Atmos. Environ. 38 (2004) 2045-2054.

[34] European Environmental Agency (EEA), More EU Member States to Miss 2010 Air Pollutant Limits, Available at

http://www.eea.europa.eu/highlights/more-eumember-statesto-miss-2010-air-pollutant-limits, accessed online September 2010.

[35] European Environmental Agency (EEA), Beyond Transport Policy - Exploring and

Managing the External Drivers of Transport Demand: Illustrative Case Studies from Europe, EEA Technical Report No. 12, EEA, Copenhagen, 2008.

[36] N. Schiavon, G. Chiavari, D. Fabbri, Soiling of limestone in an urban environment characterized by heavy vehicular exhaust emissions, Environ. Geol. 46 (2004) 448-455.

[37] Portuguese Environmental Agency, QualAr, Online Database of Air Quality, Available at http://www.qualar.org/?page=1, accessed in September-October 2010. 
[38] European Union, (EU), Directive 2008/50/EC of the European Parliament and of the Council on ambient air quality and cleaner air for Europe, Official J. European Union L152 (2008) 1-44.

[39] Portuguese Environmental Agency, Relatório do Estado do Ambiente 2008, Portuguese Environmental Agency, Lisbon, 2008.

[40] C. Oliveira, C. Pio, A. Caseiro, P. Santos, T. Nunes, H. Mao, L. Luahana, R. Sokhi, Road traffic impact on urban atmospheric aerosol loading at Oporto, Portugal, Atmos, Environ. 44 (2010) 3147-3158.

[41] K. Slezakova, M.C. Pereira, M.A. Reis, M.C.M. AlvimFerraz, Influence of traffic emissions on composition of atmospheric particles of different sizes - Part 1: concentrations and elemental characterization, J. Atmos. Chem. 58 (2007) 55-68.

[42] R. Van Dingenen, F. Raes, J.P. Putaud, U. Baltensperger, A. Charron, M.C. Facchini, S. Decesari, S. Fuzzi, R. Gehrig, H.C. Hansson, R.M. Harrison, C. Hüglin, A.M. Jones, P. Laj, G. Lorbeer, W. Maenhaut, F. Palmgren, X. Querol, S. Rodriguez, J. Schneider,

H.T. Brink, P. Tunved, K. Tørseth, B. Wehner, E. Weingartner, A. Wiedensohler,

P. Wåhlin, A European aerosol phenomenology - 1: physical characteristics of particulate matter at kerbside, urban, rural and background sites in Europe, Atmos. Environ. 38 (2004) 2561-2577.

[43] K. Ravindra, L. Bencs, E. Wauters, J. de Hoog, F. Deutsch, E. Roekens, N. Bleux, P. Bergmans, R. Van Grieken, Seasonal and site specific variation in vapor and aerosol phase PAHs over Flanders (Belgium) and their relation with anthropogenic activities, Atmos. Environ. 40 (2006) 771-785.

[44] D.J.T. Smith, R.M. Harrison, Polycyclic Aromatic Hydrocarbons in Atmospheric Particles, in: R.M. Harrison, R. Van Grieken (Eds.), Atmospheric Particles, John Wiley \& Sons, New York, 1998.

[45] H. Guo, S.C. Lee, K.F. Ho, X.M. Wang, S.C. Zou, Particle-associated polycyclic aromatic hydrocarbons in urban air of Hong Kong, Atmos. Environ. 37 (2003) 5307-5317.

[46] L.C. Marr, T.W. Kirchstetter, R.A. Harley, A.H. Miguel, S.V. Hering, S.K. Hammond, Characterization of polycyclic aromatic hydrocarbons in motor vehicles fuels and exhaust emissions, Environ. Sci. Technol. 33 (1999) 3091-3099.

[47] A.H. Miguel, T.W. Kirchstetter, R.B. Harley, R.A. Hering, On-road emissions of particulate polycyclic aromatic hydrocarbons and black carbon from gasoline and diesel vehicles, Environ. Sci. Technol. 32 (1998) 450-455.

[48] R. Chirico, P. Spezzano, D. Cataldi, Gas-particle partitioning of polycyclic aromatic hydrocarbons during the spring and summer in a suburban site near major traffic arteries, Polycycl. Aromat. Compd. 27 (2007) 401-423.

[49] K. Slezakova, D. Castro, M.C. Pereira, S. Morais, C.
Delerue-Matos, M.C.M. Alvim- Ferraz, Influence of traffic emissions on the carcinogenic polycyclic aromatic hydrocarbons in outdoor breathable particles, J. Air Waste Manage. Assoc. 60 (2010) 393-401.

[50] D. Castro, K. Slezakova, C. Delerue-Matos, M.C. AlvimFerraz, S. Morais, M.C.M. Pereira, Contribution of traffic and tobacco smoke in the distribution of polycyclic aromatic hydrocarbons on outdoor and indoor PM2.5, Glob. Nest. J. 12 (2010) 3-11.

[51] I.T.K. Nisbet, P.K. LaGoy, Toxic equivalency factors (TEFs) for polycyclic aromatic hydrocarbons (PAHs), Regul. Toxicol. Pharm. 16 (1992) 290-300.

[52] C.E. Boström, P. Gerde, A. Hanberg, B. Jernstrom, C. Johansson, T. Kyrklund, A. Rannug, M. Tornqvist, K. Victorin, R. Westerholm, Cancer risk assessments, indicators, and guidelines for polycyclic aromatic hydrocarbons in the ambient air, Environ. Health Perspect. 110 (2002) 451-488.

[53] A. Begonha, M.A. Sequeira, F. Braga, Gomes da Silva, Rain Water as a Source of the Soluble Salts Responsible for Stone Decay in the Granitic Monuments of Oporto and Braga - Portugal, in: J. Riederer (Ed.), Proceedings of 8th International Congress on Deterioration and Conservation of Stone, 1996, pp. 481-487.

[54] L. Paoletti, B. De Berardis, M. Diociaiuti, Physicochemical characterisation of the inhalable particular matter (PM10) in urban area: an analysis of the seasonal trend, Sci. Total Environ. 292 (2002) 265-275.

[55] R.K. Xie, H.M. Seip, J.R. Leinum, T. Winje, J.S. Xiao, Chemical characterization of the individual particles (PM10) from ambient air in Guiyang City, China, Sci. Total Environ. 343 (2005) 261-272.

[56] K. Slezakova, M.C. Pereira, J.M.C. Pires, F.G. Martins, M.C.M. Alvim-Ferraz, Influence of traffic emissions on composition of atmospheric particles of different sizes - Part 2: SEM-EDS characterization, J. Atmos. Chem. 60 (2008) 221-236.

[57] J.C.M. Pires, S.I.V. Sousa, M.C. Pereira, M.C.M. AlvimFerraz, F.G. Martins, Management of air quality monitoring using principal component and cluster analysis - Part I: SO2 and PM10, Atmos. Environ. 42 (2008) 1249-1260. [58] N. Vardar, F. Esen, Y. Tasdemir, Seasonal concentrations

in a suburban site of Bursa, Turkey. Environ. Pollut. 155 (2008) 298-307.

[59] F. Tittarelli, G. Moriconi, A. Bonazza, Atmospheric deterioration of cementplaster in a building exposed to a urban environment, J. Cult. Herit. 9 (2008) 203-206.

[60] World Health Organization (WHO), Air Quality Guidelines: Second Edition, European Series No. 91, WHO Regional Publications, Copenhagen, 2000. 